Universidad de Lima

Facultad de Derecho

Carrera de Derecho

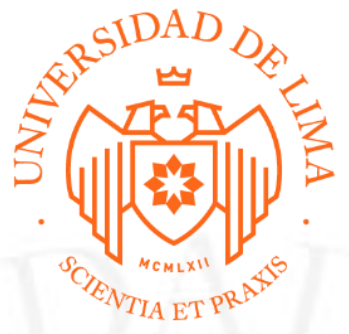

\title{
CIVIL: "DIVORCIO POR CAUSAL" Y ADMINISTRATIVO: "PROTECCIÓN AL CONSUMIDOR"
}

Trabajo de suficiencia profesional para optar el Título Profesional de Abogado

\author{
Velarde Cotrina, Hillary Francesca
}

Código 20111319

Lima - Perú

Julio de 2019 


\section{CIVIL: "DIVORCIO POR CAUSAL"}

Expediente: DE-FAM0297

Materia: Divorcio por causal

Juzgado: $8^{\text {vo }}$ Juzgado Familia

Vía Procedimental: Conocimiento

\section{RESUMEN}

La Sra. S. P. interpone demanda de divorcio contra T. C. por las causales de imposibilidad de hacer vida en común, violencia física y sicológica, atentado contra la vida del cónyuge y abandono injustificado de la casa conyugal, como pretensión accesoria solicitó una pensión de alimentos para su menor hijo nacido dentro del matrimonio y un régimen de visitas para el demandado.

\section{ADMINISTRATIVO: "PROTECCIÓN AL CONSUMIDOR"}

Materia: Protección al Consumidor.

Expediente: DE-INDEC0474

RESUMEN

El Sr. C. T. interpone denuncia contra Inversiones XXXX E.I.R.L ante la Oficina Regional de INDECOPI de Cusco por presuntas infracciones a los artículos 38.1 y 152 del Código de Protección y defensa del Consumidor, es decir discriminación por su opción sexual al no permitírsele el ingreso a la Discoteca XXXX, propiedad del denunciado, y negarle la entrega del libro de reclamaciones cuando éste se le fue solicitado, respectivamente. 